\title{
Long-term dynamics of aboveground fungal communities in a subalpine Norway spruce forest under elevated nitrogen input
}

\author{
François Gillet • Martina Peter • François Ayer • \\ Rita Bütler $\cdot$ Simon Egli
}

Received: 20 December 2009/Accepted: 17 May 2010/Published online: 4 June 2010

(C) Springer-Verlag 2010

\begin{abstract}
As anthropogenic $\mathrm{N}$ deposition has been suspected to be the main reason for the decline of macromycetous sporocarp production in forest ecosystems, various $\mathrm{N}$-fertilization experiments were started in the mid 1990s. The dynamics of ectomycorrhizal (root-inhabiting) and terricolous saprobic (litter-inhabiting) fungal communities were studied by exhaustive sporocarp inventories in a substitution Norway spruce (Picea abies) forest in two 256$\mathrm{m}^{2}$ plots sampled for periods of 1 week at $1-\mathrm{m}^{2}$ resolution between 1994 and 2007. N was added to the soil twice per year in one plot from the fourth year onwards. The effects of $\mathrm{N}$ input and time on aboveground fungal communities were assessed using redundancy analysis, principal response curves and non-parametric multivariate ANOVA. Results of this long-term experiment revealed that both ectomycorrhizal and saprobic fungal communities responded to an increase in soil $\mathrm{N}$ input. The ectomycorrhizal community reacted by a fast decrease in sporocarp
\end{abstract}

Communicated by Bernhard Schmid.

Electronic supplementary material The online version of this article (doi:10.1007/s00442-010-1668-3) contains supplementary material, which is available to authorized users.

F. Gillet $(\bowtie)$

CNRS, UMR 6249 Chrono-environnement, Université de

Franche-Comté, 16 route de Gray, 25030 Besançon Cedex, France

e-mail: francois.gillet@univ-fcomte.fr

F. Gillet

Ecological Systems Laboratory, Ecole Polytechnique Fédérale de Lausanne, Station 2, 1015 Lausanne, Switzerland

M. Peter · F. Ayer $\cdot$ R. Bütler $\cdot$ S. Egli

Swiss Federal Research Institute WSL, Zürcherstrasse 111, 8903 Birmensdorf, Switzerland production and in species richness, whereas the saprobic community was less affected. The response was highly species specific, especially for the saprobic community. The difference in species composition between control and fertilized plots was significant after 1 year of $\mathrm{N}$ addition for ectomycorrhizal fungi and only after 3 years for saprobic fungi. An aging effect affected sporocarp production in the whole area. For both communities, this unidirectional drift in species composition was as important as the treatment effect. This result highlights the importance of considering the respective role of treatment and year effects in longterm field experiments on fungal communities.

Keywords Ectomycorrhizal fungi .

Principal response curves - Redundancy analysis .

Saprobic fungi $\cdot$ Sporocarp production

\section{Introduction}

Macrofungi play important ecological roles in forest ecosystems as mycorrhizal symbionts, decomposers, and pathogens (Dix and Webster 1995). Mycorrhizal fungi increase the absorptive capacity of roots and increase resistance to disease, drought and extreme temperatures (Smith and Read 2008). Saprobic fungi are very important for the decomposition of organic matter and the return of its constituents to nutrient cycles.

A decline in species richness and abundance of macromycetous sporocarps was reported in Europe in the 1980s, in particular that of ectomycorrhizal species (Arnolds 1991). Similar trends were observed in long-term inventories of macromycetes in a Swiss forest ecosystem, in which the proportion of ectomycorrhizal species decreased compared to that of the saprotrophs from the 1980s (Egli 
and Ayer 1997). Enhanced soil $\mathrm{N}$ availability was hypothesized to be the main reason for such changes (Arnolds 1991; Rühling and Tyler 1991).

Until the middle of the twentieth century, $\mathrm{N}$ acted as a growth-limiting element in most coniferous forests in the northern hemisphere (Berg and Verhoef 1998). In the most $\mathrm{N}$-limited forest ecosystems in northern Sweden, fertilization with $\mathrm{N}$ has been widely practised since the mid 1960s. Typically, a single dose of $150 \mathrm{~kg} \mathrm{~N} \mathrm{ha}^{-1}, 10$ years before harvest, increased stem production by $10-20 \mathrm{~m}^{3} \mathrm{ha}^{-1}$ (Demoling et al. 2008). Apart from increasing tree growth, $\mathrm{N}$ fertilization could affect forest ecosystems in other ways, such as reduced biodiversity of plants, mosses and lichens and ectomycorrhizal fungi. The increasing awareness of the deposition of air-pollution $\mathrm{N}$ and its possible effects have raised serious concerns regarding the suitability of fertilizing forests with $\mathrm{N}$ (Nohrstedt 2001).

Atmospheric $\mathrm{N}$ deposition has strongly increased on a global scale during the last decades due to increasing human activities. $\mathrm{N}$ is deposited as inorganic compounds, mainly as $\mathrm{NO}_{3}{ }^{-}$emitted by combustion processes and $\mathrm{NH}_{4}{ }^{+}$emitted by agricultural activities. In Switzerland current annual rates of $\mathrm{N}$ deposition are between $5 \mathrm{~kg} \mathrm{~N}^{-1}$ year $^{-1}$ in mountain regions and $60 \mathrm{~kg} \mathrm{~N} \mathrm{ha}^{-1}$ year $^{-1}$ in regions with intensive livestock farming (Bassin et al. 2007). Because $\mathrm{N}$ emissions still exceeded the targeted pre-1950 level (BUWAL 1995), and because of concerns about the potential threat of elevated $\mathrm{N}$ inputs to the stability of forest ecosystems, various fertilization experiments started in the mid 1990s.

Increasing $\mathrm{NO}_{3}{ }^{-}$and $\mathrm{NH}_{4}{ }^{+}$inputs in forest ecosystems have been shown to reduce ectomycorrhizal mycelium growth in the soil (Arnebrant 1994; Nilsson and Wallander 2003) and to decrease the species diversity and sporocarp production of ectomycorrhizal species, whereas saprobic species are much less affected (Ritter and Tölle 1978; Arnolds 1991; Wiklund et al. 1995; Wallenda and Kottke 1998; Lilleskov et al. 2001; Peter et al. 2001a; Trudell and Edmonds 2004). The diverse ways of $\mathrm{C}$ acquisition of ectomycorrhizal and saprobic fungi might explain the different reactions of the two communities to $\mathrm{N}$ input. Ectomycorrhizal fungi are directly dependent on the $\mathrm{C}$ supply from trees. When $\mathrm{N}$ availability in the soil is high, trees reduce $\mathrm{C}$ allocation to the roots and reduce investment of $\mathrm{C}$ in mycorrhizal fungi (Demoling et al. 2008; Högberg et al. 2007). However, there are few ectomycorrhizal species, such as Paxillus involutus and Lactarius rufus, and species of the Thelephoraceae and Corticiaceae which have been reported to remain unaffected, or even to increase their production of sporocarps in forest soils to which $\mathrm{N}$ has been added (Laiho 1970; Ohenoja 1978; Wästerlund 1982; Peter et al. 2001a). It is well known that ectomycorrhizal species can have saprobic capacities (Koide et al. 2008). Species that remain unaffected or even increase in abundance after $\mathrm{N}$ addition might therefore be able to use other $\mathrm{C}$ sources than the one provided by the plant host.

In 1994 an $\mathrm{N}$-addition long-term experiment was planned in a subalpine Norway spruce stand in the Swiss PreAlps where detailed macromycete sporocarp surveys had been carried out for 3 years before starting the fertilization treatment. The experiment started in 1997, using a longterm fertilizer, which should simulate a continuing, high $\mathrm{N}$ deposition on the forest soil. Partial results of this experiment have been reported, including effects of 2-year $\mathrm{N}$ fertilization on both aboveground and belowground ectomycorrhizal fungal communities (Peter et al. 2001a). Sporocarp surveys showed that diversity of the ectomycorrhizal community was drastically reduced following 1 year of $\mathrm{N}$ addition, whereas the impact on belowground ectomycorrhizal diversity was less pronounced with no change either in the number of ectomycorrhizal taxa or in Simpson's index of diversity. However, a change in belowground species composition 2 years after $\mathrm{N}$ addition was observed with significant changes in abundances of single species. Addition of $\mathrm{N}$ caused a shift in ectomycorrhizal abundance from species forming large sporocarps to species with no or resupinate sporocarps. Unlike the ectomycorrhizal species, the sporocarp production of saprobic species was not affected by the treatment.

The objective of the present paper is to report the further development in the response of the aboveground ectomycorrhizal and saprobic fungal communities to 11 years of $\mathrm{N}$ addition. Furthermore, we focus on the difference in treatment and year effects between the ectomycorrhizal and the saprobic aboveground communities. The specific aims were: (1) to monitor the responses of ectomycorrhizal and saprobic sporocarp production to $\mathrm{N}$ addition over time, (2) to compare the compositional changes in the fungal community between the fertilized and control plots, (3) to detect species that respond positively or negatively to $\mathrm{N}$ addition in their relative contribution to the aboveground fungal communities.

Statistical analyses were based on the following working hypotheses: (1) the negative impact of $\mathrm{N}$ addition on sporocarp density and species richness is higher for the ectomycorrhizal community than for the saprobic community, (2) the treatment effect on species composition is higher than the year effect due to either seasonal climatic fluctuations or to the aging of the ecosystem.

\section{Materials and methods}

Study site

The Parabock study site (Cerniat FR, Switzerland) was part of a reforestation project that started in the late nineteenth 
century with the aim of reestablishing native forest in a region affected by area-wide harvesting and clear-cutting since the seventeenth century. The experiment was performed in a Norway spruce (Picea abies) substitution forest. Five-year-old saplings were planted in 1960 in an old pasture, 34 years before the beginning of the survey. The tree stand was therefore monospecific, with a closed canopy and without any understorey vegetation. The forest was managed conventionally prior to the start of the experiment to get a stem density of $2,800 \mathrm{ha}^{-1}$ in 2007 .

The site is located in the Flysch zone at 1,350 m a.s.l., on an even slope (20\%) with a north-east aspect. The soil is a dystric gleysol (FAO-UNESCO 1997) with a mean topsoil $\mathrm{pH}\left(\mathrm{CaCl}_{2}\right.$ 0.01 M; soil:solution 1:2) of 4.0. The mean annual precipitation is about $2,000 \mathrm{~mm}$. The average atmospheric $\mathrm{N}$ input in this region was estimated to be about $20 \mathrm{~kg} \mathrm{~N} \mathrm{ha}^{-1}$ year $^{-1}$ (BAFU 2007). Some selected soil characteristics $[\mathrm{pH}, \mathrm{C} / \mathrm{N}$ ratio, cation exchange capacity, base saturation (BS) and BS/Al ratio] of the upper $10-\mathrm{cm}$ soil layer for 1997 prior to the start of treatment, 1999 and 2008 are shown in Table 1.

\section{Experimental design}

To assess the effects of $\mathrm{N}$ addition, we used a clumped segregation design with two $16-\mathrm{m} \times 16-\mathrm{m}$ plots, one for the control and one for the $\mathrm{N}$ treatment, each divided into four subplots of $8 \mathrm{~m} \times 8 \mathrm{~m}$ (Peter et al. 2001a). A buffering zone of $10 \mathrm{~m}$ separated the two plots. A clumped segregation of treatments was chosen rather than the desired interspersion of replicates from both treatments (Hurlbert 1984) to avoid the risk of the control plot being affected by $\mathrm{N}$ leaching due to runoff along the slope. For this reason, the $\mathrm{N}$ treatment was allocated to the plot at the lowest elevation. Due to the limitation of the design, the N-treatment effect was interpreted from inter-plot differences over time after accounting for any possible confounding effect.
$\mathrm{NH}_{4} \mathrm{NO}_{3}$ fertilizer was added at $150 \mathrm{~kg} \mathrm{~N} \mathrm{ha}^{-1}$ year $^{-1}$. The addition was applied to an area $20 \mathrm{~m} \times 20 \mathrm{~m}$ to obtain a fertilized zone of $2 \mathrm{~m}$ surrounding the $\mathrm{N}$-treatment plot. We used a long-term pure $\mathrm{N}$ fertilizer in solid, globular form (Osmocote $23+0+0,5-6 \mathrm{M}$, with equal proportions of $\mathrm{NH}_{4}{ }^{+}$and $\mathrm{NO}_{3}{ }^{-}$; Hauert Dünger, Switzerland) in which the nutrient was wrapped in an organic mantle and continuously released over 5-6 months. The globules were added twice per year in May and October, from spring 1997 onwards.

\section{Sporocarp survey}

Sporocarp surveys were carried out in a total area of $512 \mathrm{~m}^{2}$ (eight subplots of $8 \mathrm{~m} \times 8 \mathrm{~m}$ ), divided into $1-\mathrm{m}^{2}$ cells. The survey started in 1994, three years before starting the fertilization treatment. Between 1994 and 2007 a full inventory of the macromycetes was performed on the entire inventory area. At weekly intervals, all sporocarps were identified, counted, and mapped with a resolution of $1 \mathrm{~m}^{2}$. The inventories started in week 18 and ended by the onset of winter. To avoid double counting, mapped sporocarps were marked with methylene blue.

Initial sporocarp surveys, before the beginning of the Naddition experiment, had shown that the spatial distribution of fungal species at this site was not affected by any gradient (Peter et al. 2001a, b).

The dataset was split into two community tables, one for ectomycorrhizal species and one for saprobic (terricolous, litter-inhabiting) species. Wood-inhabiting and parasitic fungal species are excluded from this study.

\section{Data analysis}

Fungi abundances were measured in terms of total numbers of sporocarps observed yearly in each plot (experimental unit) or subplot and for every species. To reduce the weight

Table 1 Selected soil chemical characteristics of the upper soil layer (Ah) at the experimental site Parabock

\begin{tabular}{|c|c|c|c|c|c|c|c|c|c|c|c|}
\hline & \multicolumn{3}{|l|}{$\mathrm{pH}\left(\mathrm{CaCl}_{2}\right)^{\mathrm{a}}$} & \multicolumn{2}{|c|}{$\mathrm{C} / \mathrm{N}$ ratio } & \multicolumn{2}{|c|}{$\operatorname{CEC}\left(\mathrm{cmol} \mathrm{kg}^{-1}\right)$} & \multicolumn{2}{|c|}{ Base saturation (\%) } & \multicolumn{2}{|c|}{$\mathrm{BC} / \mathrm{Al}$ ratio } \\
\hline & C plot & $\mathrm{N}$ plot & Sig. & C plot & $\mathrm{N}$ plot & C plot & $\mathrm{N}$ plot & C plot & $\mathrm{N}$ plot & C plot & $\mathrm{N}$ plot \\
\hline $1997^{\mathrm{b}}$ & $3.95 \pm 0.05 \mathrm{a}$ & $3.89 \pm 0.02 \mathrm{a}$ & n.s. & 11.9 & 12.0 & - & - & - & - & - & - \\
\hline 1999 & $4.01 \pm 0.04 \mathrm{a}$ & $3.85 \pm 0.02 \mathrm{a}$ & ** & 13.3 & 13.0 & - & - & - & - & - & - \\
\hline 2008 & $3.95 \pm 0.06 \mathrm{a}$ & $3.49 \pm 0.08 b$ & $* * *$ & 15.6 & 15.9 & 22.4 & 19.0 & 84 & 46 & 8.9 & 1.0 \\
\hline
\end{tabular}

The values were determined on sieved and dried soil samples. Except for $\mathrm{pH}$ measurements, composite samples of 16 soil cores $(4.5 \mathrm{~cm}$ diameter; 0-10 cm depth) per plot were used

$C$ control plot, $N$ N-fertilized plot, $C E C$ cation exchange capacity $\left(\mathrm{cmol} \mathrm{kg}^{-1}\right), B C / A l$ ratio, ratio of base cations $(\mathrm{Ca}, \mathrm{Mg}, \mathrm{K}, \mathrm{Na})$ to aluminium, sig significance between treatments within years, n.s. not significant

** $P \leq 0.01, * * * P \leq 0.001$

${ }^{\text {a }}$ Mean values $(n=18-24) \pm$ SE. Different letters within columns indicate significant differences within treatment among years $(P \leq 0.05$, Bonferroni)

b Before start of $\mathrm{N}$ fertilization 
of species with very high sporocarp numbers, all raw abundance values $y$ were $\log$-transformed by $\ln (y+1)$ prior to multivariate analyses.

All statistical analyses were computed with R 2.7.2 (R Development Core Team 2008) and the vegan library (Oksanen et al. 2008).

\section{Sporocarp density and species richness}

Average sporocarp density and species richness were calculated for each fungal community in each subplot at each sampling year. Results were described by lineplots of the mean and SE of the response variable for a two-way experimental design. Parametric ANOVA was used to test the difference in both responses between control and fertilized subplots for each year.

\section{Redundancy analyses}

Redundancy analysis (RDA) was applied separately to ectomycorrhizal and terricolous saprobic fungal communities at plot scale (no replication), using Treatment (a binary variable with two levels: $\mathrm{N}$ for $\mathrm{N}$ addition and $\mathrm{C}$ for control) and Year (a quantitative variable between 1994 and 2007) as explanatory variables (Legendre and Legendre 1998). The interaction between Treatment and Year, which was not significant, was not included in the model. The significance of the explanatory variables was tested using 1,000 permutations.

This constrained ordination method provides a multivariate regression model of the response of the fungal communities to $\mathrm{N}$ addition and time. Treatment was coded $\mathrm{C}$ for pre-treatments years in both plots. Year was regarded as quantitative as we were looking for the effect of a temporal gradient. Each community dataset was transformed into 'site profiles' (compositional data) to avoid considering double absence of a species as a resemblance between observations, using Hellinger standardization: abundances were replaced by the square root of the relative log-transformed abundances per plot (Legendre and Gallagher 2001). As compared to more conventional canonical correspondence analysis using 'double profiles', RDA based on Hellinger distance also assumes a unimodal response of species to environmental gradients but without giving much weight to rare species. Using this transformation of data, the comparison of trajectories over time for site profiles in fertilized and control plots does not take into account the effect of Treatment and Year on the total (absolute) sporocarp abundance per year. This approach is therefore able to detect changes in the overall relative species composition of the two plots, which can be partly explained by the treatment and by uncontrolled changes in the environment (Dray et al. 2003).
Additionally, variation partitioning using RDA and adjusted $R^{2}$ (Peres-Neto et al. 2006) was applied to compare the respective effect of each explanatory variable, alone or in combination. We used the varpart function of the vegan library to partition the variation of the response table (Hellinger-transformed species matrix) with respect to the two explanatory variables Treatment and Year and their joint effect (shared explained variation; Borcard et al. 1992), using a series of RDAs and partial RDAs.

\section{Principal response curves}

The principal response curve (PRC) method (van den Brink and ter Braak 1998, 1999; Moser et al. 2007) was used to focus on the time-dependent treatment effect on the Hellinger-transformed fungal communities as well as on the response of individual species. PRC analysis is a special case of partial RDA (pRDA) for multivariate responses in repeated observation design. It is based on a pRDA adjusted for overall changes in community response over time, as compared to control plots. The pRDA model was defined as the multivariate response to the Treatment $\times$ Year interactions, conditioned by Year. Year was considered as a qualitative factor with 14 levels. Accordingly, the sampling years were used as covariables in the pRDA model, whereas the interactions between the $\mathrm{N}$ treatment and the sampling years stood as explanatory variables. Here, Treatment was coded $\mathrm{N}$ for pre-treatment years in the fertilized plot, in order to assess the possible differences between fungal communities in $\mathrm{N}$ and $\mathrm{C}$ subplots before $\mathrm{N}$ addition.

For PRC analyses, we used datasets made of repeated observations on four $8-\mathrm{m} \times 8-\mathrm{m}$ subplots inside each experimental plot. Although these subplots should not be considered as true replicates because of the clumped segregation design (Hurlbert 1984; but see Oksanen 2001, 2004), they allow testing the impact of spatial heterogeneity on the community response to treatment inside each experimental plot. Permutation tests with 1,000 permutations, stratified by year, were performed for every canonical axis and a PRC was plotted for each significant axis. The first principal component of the pRDA was plotted against time to get the first PRC (PRC1) of the whole community for the treatment, together with a quantitative interpretation of effects towards the species level (species scores). The species scores allow an interpretation at the species level: the score is the multiple by which the principal curve must be multiplied to obtain the fitted response curve of the respective species. The higher the score, the more the actual response pattern of the species is likely to follow the pattern in the PRC. Taxa with high negative scores are inferred to show the opposite pattern, whereas taxa with near zero scores either show no response or a response unrelated to the pattern shown in PRC. 


\section{Multivariate ANOVA using distance matrices}

To test differences in species composition between $\mathrm{C}$ and $\mathrm{N}$ plots within each year, including the three pre-treatment years, non-parametric multivariate ANOVA (MANOVA) was performed using the method described by Anderson (2001) and McArdle and Anderson (2001) and implemented in vegan's adonis function. It is a robust alternative to parametric MANOVA for describing how variation is attributed to different experimental treatments by use of distance matrices. Each full raw dataset was split by year, empty species and subplots were removed, abundances were log-transformed and Hellinger standardization was applied, to get one response matrix per year and per fungal community. Sums of squares of the multivariate response datasets were partitioned among treatments using Hellinger distance matrices and sum-to-zero contrasts (Crawley 2002). Significance tests were done using $F$-tests based on sequential sums of squares from 1,000 permutations of the raw data for each sampling year. We can then verify that differences between $\mathrm{C}$ and $\mathrm{N}$ plots were significant only after the start of the experiment, from 1997, suggesting that the potential confounding effects of pseudoreplication should not be as important as compared to the $\mathrm{N}$-addition effect.

\section{Results}

Sporocarp density and species richness

In the 14 years of sporocarp survey, 44 ectomycorrhizal and 43 saprobic taxa were observed on the inventoried experimental plots of $512 \mathrm{~m}^{2}$.

Sporocarp density for all ectomycorrhizal species was systematically lower in the fertilized subplots as compared to control subplots, but the difference was particularly large between 1999 and 2002 (Fig. 1a), due to the high abundance of some species in the control plot, such as Clavulina cristata (see Online Resource 1).

By contrast, sporocarp density of saprobic fungi was quite similar in both plots (Fig. 1b). From 2004 an important increase was observed in some $\mathrm{C}$ and $\mathrm{N}$ subplots. This was mainly due to a few species, which produced a lot of sporocarps in certain years, such as Clitocybe ditopa (2004, 2005) and Cudonia confusa (2005-2007; see Online Resource 1). In the exceptionally hot and dry season of 2003 , the number of sporocarps was very low for ectomycorrhizal species in both plots, whereas sporocarp production was a bit higher for saprobic fungi in the fertilized plot compared to the control.

Species richness of the ectomycorrhizal community showed moderate variation of between five and nine
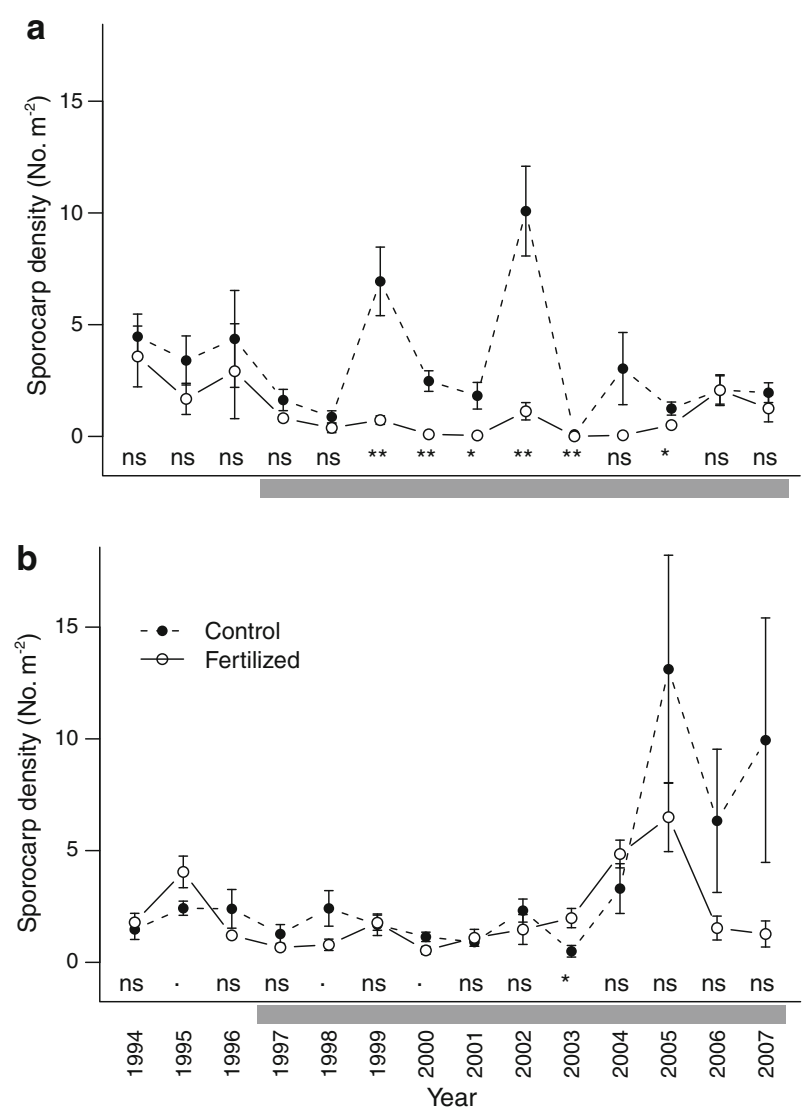

Fig. 1 Time series of yearly sporocarp density (no. sporocarps $\mathrm{m}^{-2}$, mean $\pm \mathrm{SE}$ ) of $\mathbf{a}$ ectomycorrhizal and $\mathbf{b}$ saprobic fungal communities in control $(n=4)$ and fertilized $(n=4)$ subplots; 1994, 1995 and 1996 were pre-treatment years. Grey bar denotes treatment years. Results of ANOVA are given for each year. $* P \leq 0.05$, **P $\leq 0.01$, $* * * P \leq 0.001, n s$ not significant $(P \leq 0.1)$

species per $1 \mathrm{~m}^{-2}$ in the control plot, except in 2002, for which it was particularly high, and in 2003, for which it was very low (Fig. 2a). In contrast, the species number has clearly declined in fertilized subplots from 1998 with little change since then. Species richness was systematically higher in the control subplots, suggesting a possible confounding effect due to pseudoreplication. However, the difference between $\mathrm{C}$ and $\mathrm{N}$ plots was only significant for 1996 and since 1998, from 1 year after the start of the treatment period.

Differences in species richness were much less pronounced for saprobic fungi (Fig. 2b) except for 2004-2006, for which fewer species produced sporocarps in the fertilized plot. This pattern suggests that the possible negative effect of $\mathrm{N}$ addition on aboveground species richness was delayed for saprobic fungi compared to ectomycorrhizal fungi. However, species richness of both communities tended to slowly increase in the N subplots after 2003, suggesting either a recovery or a qualitative change in species composition. This will be investigated in the next section. 

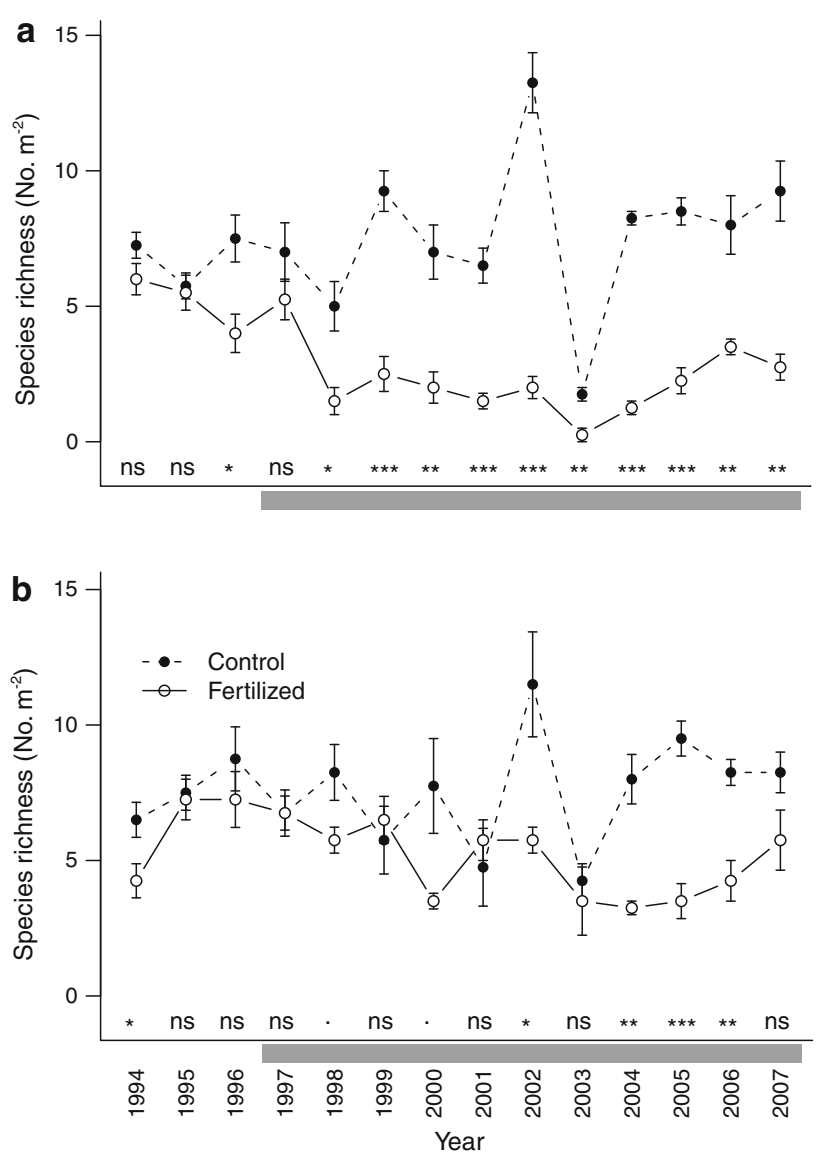

Fig. 2 Time series of yearly species richness (total species number, mean \pm SE) of $\mathbf{a}$ ectomycorrhizal and $\mathbf{b}$ saprobic fungal communities in control $(n=4)$ and fertilized $(n=4)$ subplots; 1994, 1995 and 1996 were pre-treatment years. Grey bar denotes treatment years. Results of ANOVA are given for each year. $* P \leq 0.05, * * P \leq 0.01$, $* * * P \leq 0.001, n s$ not significant $(P \leq 0.1)$

Qualitative effect of $\mathrm{N}$ addition and time on fungal communities

Species composition of the ectomycorrhizal community was strongly affected by $\mathrm{N}$ addition, as shown by the clear separation of $\mathrm{C}$ and $\mathrm{N}$ plots along the first RDA axis from 1998 (Fig. 3a). However, the analysis also suggests evidence for a linear year effect. The two variables Treatment and Year explained $33.1 \%$ of the variation in the Hellingertransformed species matrix: $21.1 \%$ on axis 1 and $12.0 \%$ on axis $2(P<0.001)$. After variation partitioning with adjusted $R^{2}$, Treatment alone explained $15.0 \%$ of the variation and Year alone $11.3 \%$, whereas the shared explained variation was only $1.5 \%$. The time course of the fertilized plot shows that species composition at the end of the experiment tended to become more similar again to that of the control plot.

A similar pattern was obtained for the saprobic community, with both treatment and year effects (Fig. 4a).
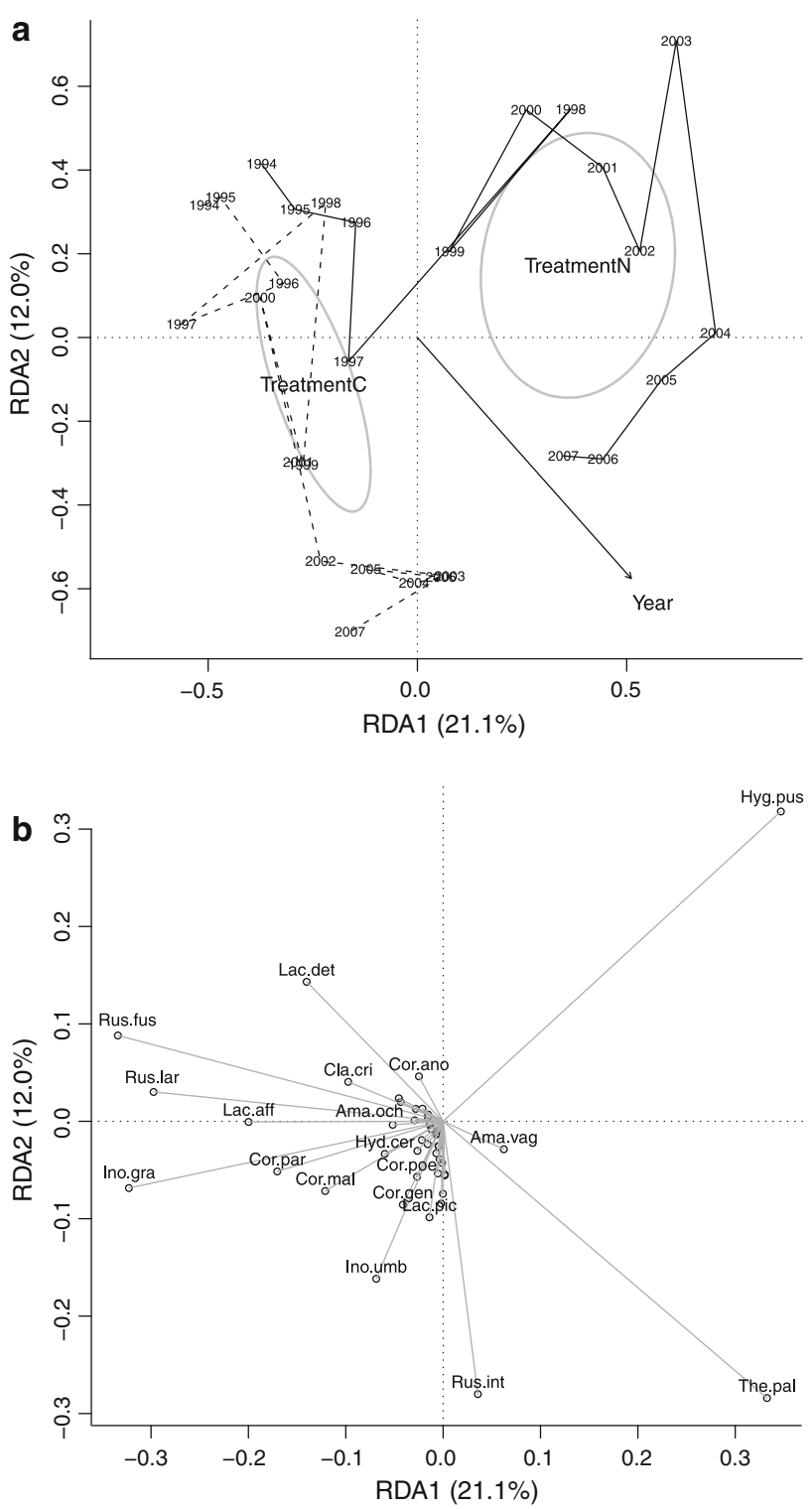

Fig. 3 Ordination diagrams (redundancy analysis; RDA) of the ectomycorrhizal fungal community composition over time in the control and fertilized plots. a Sites and explanatory variables. Treatment (binary variable) and Year (quantitative variable) were used as explanatory variables. Lines represent the time course of each treatment plot (solid line, fertilized plot; dashed line, control plot); 1994, 1995 and 1996 were pre-treatment years. Grey ellipses represent SE of site scores around the centroid of each treatment level. b Ectomycorrhizal species; only discriminating taxa that are far from the origin are labelled. Species names are given in Online resource 1 (electronic supplementary material)

These predictors explained $26.9 \%$ of the variation in the Hellinger-transformed species matrix (axis 1, 15.5\%, $P<0.001$; axis $2,11.4 \%, P<0.001$ ), which was less than for the ectomycorrhizal community. After variation partitioning with adjusted $R^{2}$, Treatment alone explained $10.8 \%$ of the variation and Year alone $12.3 \%$ without any shared explained variation. 

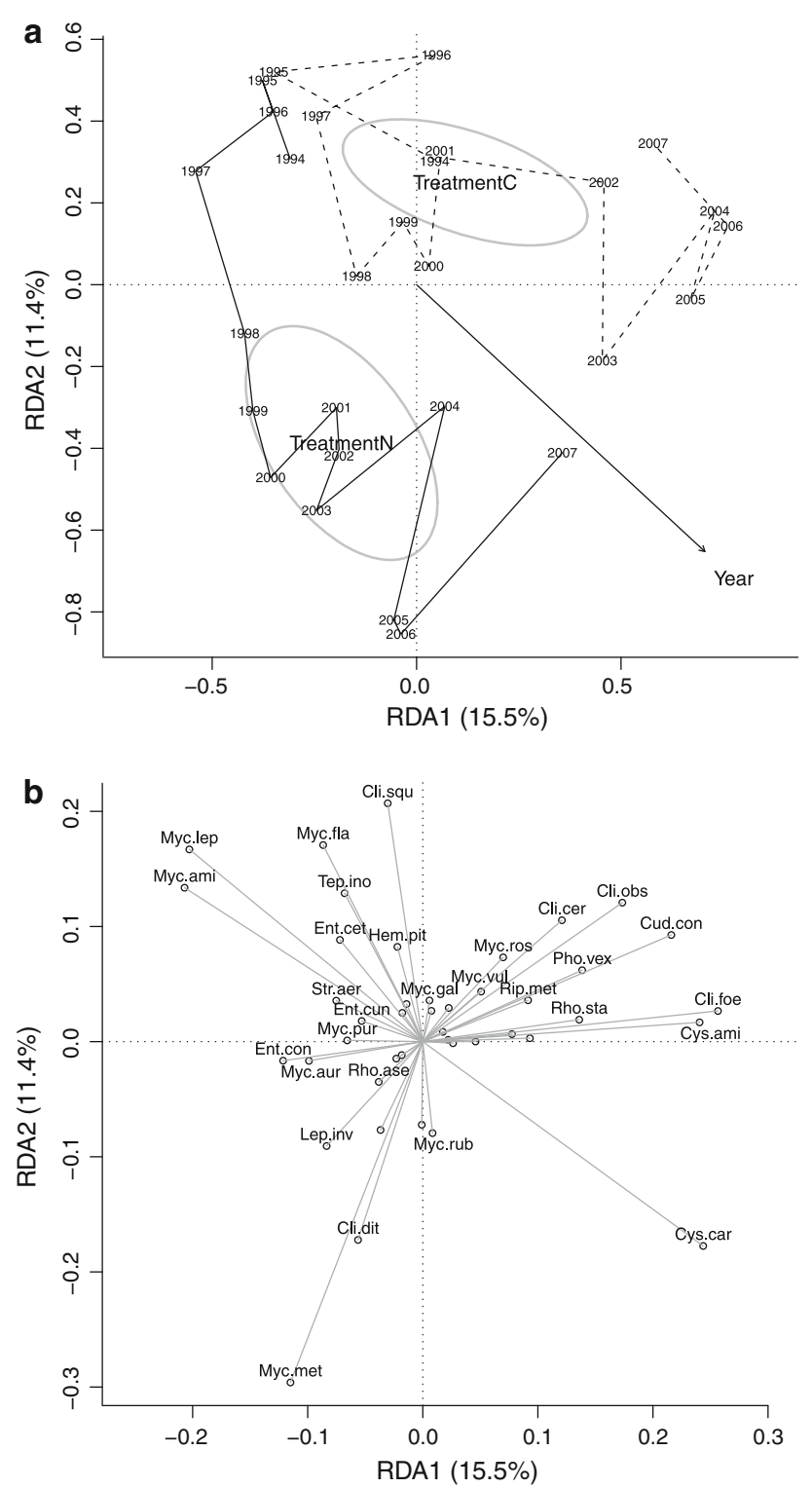

Fig. 4 Ordination diagrams (RDA) of the terricolous saprobic fungal community composition over time in the control and fertilized plots. a Sites and explanatory variables. Treatment (binary variable) and Year (quantitative variable) were used as explanatory variables. Lines represent the time course of each treatment plot (solid line, fertilized plot; dashed line, control plot); 1994, 1995 and 1996 were pretreatment years. Grey ellipses represent SE of site scores around the centroid of each treatment level. b Saprobic species; only discriminating taxa that are far from the origin are labelled. Species names are given in Online resource 1 (electronic supplementary material)

Strength of treatment effect and response of individual species

The response of the fungal communities and of the individual species to $\mathrm{N}$ addition over the years is better represented by PRC. In the diagram of PRC1 (Fig. 5), positive values of the curve indicate a positive effect of $\mathrm{N}$ treatment on species, whereas species with negative scores show the opposite pattern and are therefore expected to decrease in relative abundance. The higher the values of the curve (positive and negative), the larger are the deviations from the control.

For the ectomycorrhizal community (Fig. 5a), 23.7\% of the variation in the Hellinger-transformed species data was explained by the plot type (14 explanatory variables representing the interaction between Treatment and Year) and $32.2 \%$ by the years (14 dummy covariables). Of a total of 14 constrained pRDA axes, only the first one was significant, accounting for $14.5 \%$ of the variation $(F=13.5, P<0.001)$. The response of $\mathrm{N}$ plot to treatment appeared clearly from 1998 , one year after the beginning of the experiment. It was maximal in 2003 and tended to decrease from 2005.

Inocybe grammata and Russula fuscorubroides ceased to produce sporocarps in the $\mathrm{N}$ plot immediately after fertilization commenced, whereas they were present in the C plot over the whole, or a long period, of the study (Fig. 3b). Cortinarius parvannulatus disappeared in the third year. Other species showed a drastic reduction in numbers of sporocarps or years of appearance (Russula laricina, Clavulina cristata, Amanita ochraceomaculata), but still occurred 10 years after the fertilization treatment commenced. These species were among the most negatively affected species based on PRC analysis (Fig. 5a). In the control plot, some species, such as Russula fuscorubroides and Lactarius deterrimus, were progressively replaced by new species (e.g. Russula integra, Inocybe umbratica) across years. These species, however, did not appear in the $\mathrm{N}$-fertilized plot (Fig. 3a; Online Resource 1). Hygrophorus pustulatus was the only species for which an increase in relative sporocarp abundance was observed after $\mathrm{N}$ addition independently of the year effect (Figs. 3b, 5a). Sporocarp production of Thelephora palmata was not affected by fertilization but it was important only in the last years of the experiment (Fig. 3b; Online Resource 1).

For the saprobic community (Fig. 5b), 20.4\% of the variation was explained by the treatment and $28.0 \%$ by the years in the PRC analysis. Here too, only the first axis was significant, accounting for $10.5 \%$ of the variation $(F=8.75, \quad P<0.001)$. The treatment effect appeared progressively from 1999, two years after the beginning of the experiment. It was maximal in 2001 and 2006. PRC1 did not show a particular effect in 2003 but it appeared on PRC2 (not shown).

In contrast to ectomycorrhizal fungi, several saprobic species were favoured by $\mathrm{N}$ addition in their relative sporocarp abundance (e.g. Mycena metata, Clitocybe ditopa; Figs. 4b, 5b). However, many more species were mainly observed in control plots, such as Clitocybe foetens, Clitocybe cerussata, Clitocybe obsoleta, Cudonia confusa and Cystoderma amianthinum (Figs. 4b, 5b). Tephrocybe inolens was abundant in $\mathrm{C}$ and $\mathrm{N}$ plots at the beginning of the 

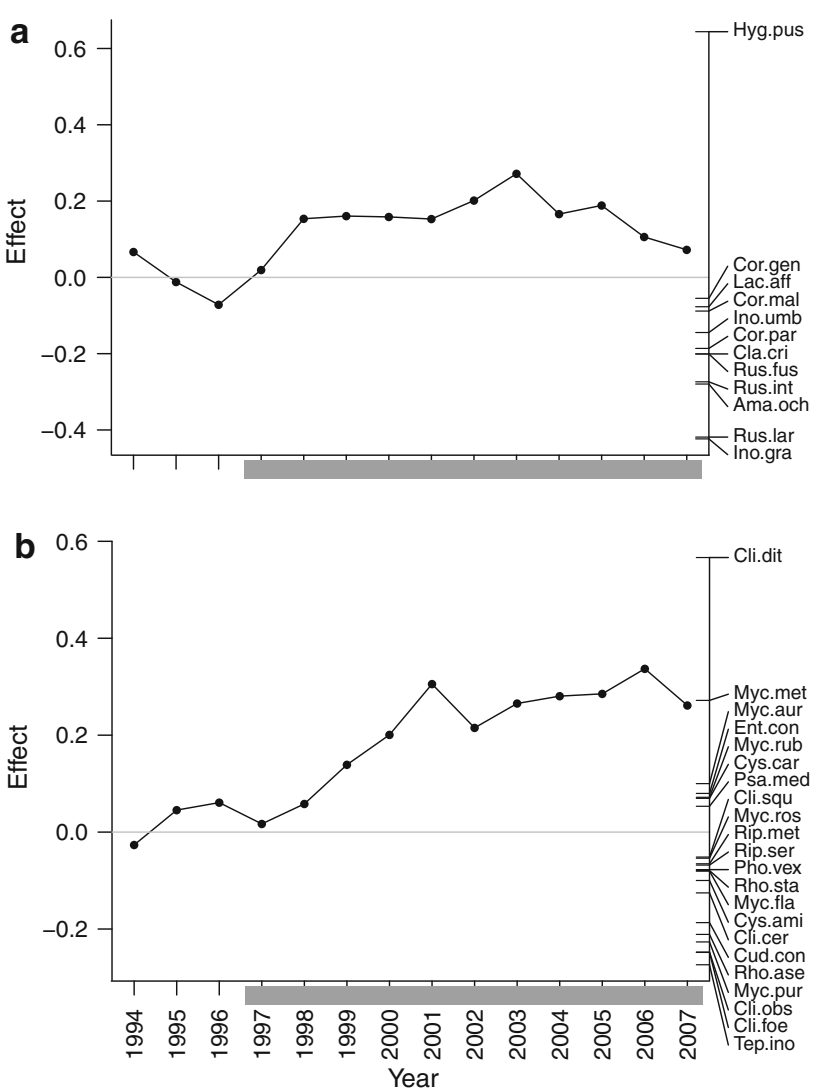

Fig. 5 First principal response curve with species scores for a ectomycorrhizal and $\mathbf{b}$ saprobic fungal communities, indicating the effect of $\mathrm{N}$ addition over time. Grey bar denotes treatment years. Only species with a score below -0.05 or above 0.05 are displayed. Species names are given in Online resource 1 (electronic supplementary material)

experiment but ceased to produce sporocarps in the $\mathrm{N}$ plot in the last 4 years (Online Resource 1).

The year effect corresponded to the decline of such species as Mycena leptocephala, Mycena amicta and Clitocybe squamulosa, and the increase in Cystoderma carcharias in both plots.

Differences in species composition at each sampling year

The previous analyses based on ordination methods were not designed to test the differences between $\mathrm{C}$ and $\mathrm{N}$ plots separately for each sampling year, including the pre-treatment years. Non-parametric MANOVA using Hellinger distance matrices were thus applied for this purpose.

For both fungal communities, it showed that there was no significant difference in species composition between the two plots before the beginning of the experiment (Table 2). The treatment effect became significant from 1998 for the ectomycorrhizal community and was delayed until 2000 for the saprobic community. It was highly significant in 2003 for the ectomycorrhizal community with $88 \%$ of explained variation. In 2003, species richness and abundance were, however, very low in both treatments (one species in $\mathrm{N}$ plots, two species in $\mathrm{C}$ plots with only few sporocarps formed; Online Resource 1).

\section{Discussion}

Response of ectomycorrhizal species to fertilization

According to the available literature there is a clear negative effect of elevated $\mathrm{N}$ levels on ectomycorrhizal communities, not only with respect to mycorrhiza diversity, colonization rate and growth of external mycelium, but also on the production of sporocarps. However, the response in sporocarp production can vary strongly in extent and in response time. Menge and Grand (1978) already found a reduction in ectomycorrhizal sporocarp production in the first year of $\mathrm{N}$ addition (56 and $112 \mathrm{~kg} \mathrm{~N} \mathrm{ha}^{-1}$ year $^{-1}$ ). Also in a study of Termorshuizen et al. (1988), the sporocarp production decreased in the first year of the treatment. In a Swedish beech forest ectomycorrhizal species almost completely disappeared after 34 years of fertilization with $60 \mathrm{~kg} \mathrm{~N} \mathrm{ha}^{-1}$ year $^{-1}$ (Rühling and Tyler 1991). In a 30-year-old Norway spruce stand in southwestern Sweden all mycorrhizal species ceased to produce sporocarps in the 4 th year of the supply of $100 \mathrm{~kg} \mathrm{~N} \mathrm{ha}^{-1}$ year $^{-1}$ (Wiklund et al. 1995).

Hygrophorus pustulatus was the only species that tended to profit from $\mathrm{N}$ addition in our study, in accordance with results of Agerer et al. (1998) who observed a tremendous increase in the fruiting of this species in a liming and irrigation experiment (30 times more sporocarps). In a study over an atmospheric $\mathrm{N}$ deposition gradient in Alaska (Lilleskov et al. 2001), another species of this genus, Hygrophorus olivaceoalbus, was slightly positively correlated with $\mathrm{N}$ availability in the organic horizon.

Thelephora palmata, which was present in previous years, was not affected by $\mathrm{N}$ addition, but its sporocarp production drastically increased mainly in the $\mathrm{N}$ plot in the last 2 years of the study. The belowground studies performed in the same site showed an increase in mycorrhizal restriction fragment length polymorphism types belonging to the Thelephoraceae on the N plot from 1997 to 1999 (Peter et al. 2001a). It seemed, therefore, that many of these species are not negatively affected or even benefit from high $\mathrm{N}$ availability. The present finding supports this view.

Response of saprobic species to fertilization

The effect of $\mathrm{N}$ addition on saprobic species seems to be very species specific. Some species are positively 
Table 2 Inter-plot variation in ectomycorrhizal and saprobic fungal communities computed from multivariate ANOVAs with Hellinger distance matrices and permutation tests for every sampling year ( $n=4$ subplots, $d f=1,1,000$ permutations)

\begin{tabular}{|c|c|c|c|c|c|c|}
\hline \multirow[b]{2}{*}{ Year } & \multicolumn{3}{|c|}{ Ectomycorrhizal fungi } & \multicolumn{3}{|l|}{ Saprobic fungi } \\
\hline & Variation $(\%)$ & $F$ & $P$ value & Variation $(\%)$ & $F$ & $P$ value \\
\hline $1994^{\mathrm{a}}$ & 22.68 & 1.760 & 0.151 n.s. & 19.76 & 1.478 & 0.172 n.s. \\
\hline $1995^{\mathrm{a}}$ & 11.35 & 0.768 & 0.414 n.s. & 15.87 & 1.132 & 0.416 n.s. \\
\hline $1996^{\mathrm{a}}$ & 6.99 & 0.451 & 0.795 n.s. & 16.01 & 1.144 & 0.265 n.s. \\
\hline 1997 & 21.59 & 1.652 & 0.193 n.s. & 10.82 & 0.728 & 0.768 n.s. \\
\hline 1998 & 35.42 & 3.291 & $0.04 *$ & 18.43 & 1.356 & 0.247 n.s. \\
\hline 1999 & 35.19 & 3.258 & $0.011 *$ & 15.25 & 1.079 & 0.405 n.s. \\
\hline 2000 & 42.32 & 4.402 & $0.023 *$ & 31.33 & 2.738 & $<0.001 * * *$ \\
\hline 2001 & 25.47 & 2.051 & 0.114 n.s. & 45.03 & 4.916 & $<0.001 * * *$ \\
\hline 2002 & 36.81 & 3.495 & $0.025^{*}$ & 42.16 & 4.373 & $<0.001 * * *$ \\
\hline 2003 & 88.25 & 22.523 & $<0.001 * * *$ & 33.43 & 3.013 & $0.004 * *$ \\
\hline 2004 & 26.05 & 2.114 & $0.028 *$ & 44.33 & 4.777 & $0.004 * *$ \\
\hline 2005 & 35.79 & 3.345 & $0.03 *$ & 46.58 & 5.232 & $<0.001 * * *$ \\
\hline 2006 & 39.68 & 3.948 & $0.021 *$ & 45.13 & 4.934 & $0.005 * *$ \\
\hline 2007 & 39.5 & 3.918 & $<0.001 * * *$ & 33.28 & 2.992 & $0.032 *$ \\
\hline
\end{tabular}

$* P \leq 0.05, * * P \leq 0.01$, *** $P \leq 0.001$, n.s. not significant

${ }^{\text {a }}$ Pre-treatment year

influenced, whereas others are negatively affected, which explains the small effect on sporocarp abundance (Fig. 1b) and species richness (Fig. 2b). There is no tendency for a common type of behaviour at the genus level. These findings coincide with the results of other $\mathrm{N}$ fertilization experiments: they exhibit both an increase and decrease in sporocarp production of saprobic fungi after $\mathrm{N}$ addition. In a 30-year-old Norway spruce stand in southern Sweden the addition of $\left(\mathrm{NH}_{4}\right)_{2} \mathrm{SO}_{4}\left(100 \mathrm{~kg} \mathrm{ha}^{-1}\right)$ over 4 years caused a slight but not significant reduction of the number of saprobic sporocarps on the fertilized plots (Wiklund et al. 1995), except for Mycena rubromarginata which was not affected, in accordance with our results. In the study of Rühling and Tyler (1991) most of the leaf litter and humus decomposers increased their basidioma production as a result of $\mathrm{N}$ addition. In an artificial Norway spruce stand in north-eastern France, Macrolepiota rhacodes, an excellent edible mushroom, showed a greatly enhanced sporocarp biomass, from 6 to $45 \mathrm{~kg} \mathrm{ha}^{-1}$, after fertilization with $150 \mathrm{~kg} \mathrm{~N} \mathrm{ha}^{-1}$ year $^{-1}$ (Garbaye and Le Tacon 1982).

Changes of soil properties due to fertilization and their possible effects on the fungal communities

Soil abiotic factors are considered to be important in determining the distribution of ectomycorrhizal fungal species (Erland and Taylor 2002; Toljander et al. 2006). Soil base saturation, $\mathrm{pH}$ and organic matter content are among the most important factors governing the distribution of macrofungi (Agerer et al. 1998; Erland and Taylor
2002; Wallenda and Kottke 1998; Kernaghan 2005). Whereas organic matter content did not differ between the two treatments, the soil $\mathrm{pH}$ and base saturation were significantly reduced in the $\mathrm{N}$ plot in the course of our experiment (Table 1). This acidification of the soil over the 11 years of the experiment might very well be an additional cause of the observed differences in the community structure of ectomycorrhizal and saprobic fungi.

However, the relationship between sporocarp occurrence and soil $\mathrm{pH}$ is not simple; changes in a number of other soil variables, including changes in the availability of heavy metals and of essential nutrients, are concomitant with changes in soil pH (Agerer et al. 1998; Erland and Taylor 2002). As soils become acidified, Al can become more available (Lilleskov et al. 2001). In our study area, $\mathrm{Al}$ concentration in the organic horizon of the $\mathrm{N}$ plot was 4 times higher than in the control plot after 11 years of fertilization (C plot, $2.1 \mathrm{cmol} \mathrm{kg}^{-1}$, N plot, $8.7 \mathrm{cmol} \mathrm{kg}^{-1}$; data not shown). This value is high when compared with other forest soils in the Pre-Alps of Switzerland (Walthert et al. 2006). It is therefore possible that in the long run in our experiment, increased $\mathrm{Al}$ concentrations in the soil also impacted the composition of the saprobic and mycorrhizal communities.

Comparison of the effect of $\mathrm{N}$ addition on the ectomycorrhizal and saprobic communities over time

The effect of $\mathrm{N}$ addition clearly differed between the ectomycorrhizal and saprobic community. Whereas the 
ectomycorrhizal community reacted immediately after the start of fertilization with a reduced and altered species composition, the saprobes showed a significant change in community composition only 3 years after the treatment start. Unlike the situation for the saprobic community, the $\mathrm{N}$ addition effect on the ectomycorrhizal community seemed to decrease 9 years after the treatment start with the control and fertilized plot becoming more similar again. When looking at individual species, this tendency, however, was mainly caused by a reduced production of sporocarps in the control plot in the last years for species that reduced sporocarp production in the $\mathrm{N}$ plot immediately after the start of fertilization (such as A. ochraceomaculata, I. grammata, Russula laricina and Russula fuscorubroides; see Online Resource 1) rather than their recovery in the $\mathrm{N}$ plot. The richness of ectomycorrhizal species was still clearly reduced in the fertilized plot and was still less than that found before the start of the experiment.

How can we interpret these discrepancies in the reaction of the two fungal communities to $\mathrm{N}$ supply? As mentioned in the Introduction, the main difference between the two communities is the way they acquire $\mathrm{C}$, with ectomycorrhizal species being dependent on the direct $\mathrm{C}$ supply from their host plants. The immediate response of the ectomycorrhizal community to the $\mathrm{N}$ supply has been seen in several $\mathrm{N}$-fertilization experiments and studies of $\mathrm{N}$ gradients and is widely accepted to be caused by a reduced supply of plant $\mathrm{C}$ to the fungal symbionts (e.g. Högberg et al. 2007). Whereas the nutritional conditions for ectomycorrhizal species changed rapidly, the conditions for saprobic species probably changed during the course of the experiment by altered soil biogeochemistry as mentioned in the previous section. Several studies showed that $\mathrm{N}$ supply, particularly at high rates, resulted in increased and qualitatively changed soil organic matter content by slowing decomposition through lignin-degrading enzymes (Knorr et al. 2005; Pregitzer et al. 2008; Zak et al. 2008; Hassett et al. 2009). Such qualitative and quantitative changes of the litter and organic matter are likely to influence the saprobic community composition.

Changes of fungal communities over time irrespective of $\mathrm{N}$ treatment

We observed a shift over time of ectomycorrhizal and saprobic communities in both the fertilized and control plots. Besides the impact of atmospheric $\mathrm{N}$ deposition, numerous other factors are known to interact with or even govern the structure of fungal communities (Kernaghan 2005). Even if we did not monitor concomitant changes of associated ecological variables, there is some plausible evidence that some of the factors governing community structure may have been modified in our study site during the 14 years of observation. Hereafter, we will discuss some of them.

Human-induced changes of the soil properties due to land-use change

The experiment in the present study was conducted in a Norway spruce substitution forest on an ancient grassland pasture. It is possible that the observed community change is partly a consequence of this land-use conversion. During afforestation on land that previously was colonized only by non-ectomycorrhizal plants, ectomycorrhizal fungi undergo primary succession (Jones et al. 2003). In our site the fungal community structure probably started to change immediately after afforestation, i.e. about 40 years before the start of the experiment. However, it is possible that this change was still going on during the 14 years of observation, since afforestation of agricultural soil by conifer trees may cause substantial and long-term alteration in ecosystem biogeochemistry. For example, Norway spruce tends to cause or accelerate podzolisation on afforested sites (Alriksson and Olsson 1995). The $\mathrm{pH}$ was measured from the beginning of the observations and has not changed in the control plot over time. We observed, however, a clear increase in the $\mathrm{C} / \mathrm{N}$ ratio from 12 to about 16 in both treatment plots (Table 1). Compared to other forest sites, the $\mathrm{C} / \mathrm{N}$ ratios of the organic horizon, $\mathrm{Ah}$, in our site were very low, in particular in the beginning of the experiment (cf. e.g. Toljander et al. 2006; Rineau and Garbaye 2009; Walthert et al. 2006). The F horizon was small $(0-2 \mathrm{~cm})$ at the beginning of the experiment and increased to about $3 \mathrm{~cm}$ in the year 2007 (data not shown). This indicates that the humus layer was still developing during the course of our experiment from a mull type, which can be found under grassland, towards a less active moder type, which is usually found in old spruce forests (Walthert et al. 2006). It is possible that this development and the increase in $\mathrm{C}$ in the humus layer was an important driver of the change in the ectomycorrhizal as well as the saprobic community structure. Since higher C contents in the soil may favour ectomycorrhizal species that have saprobic capacities, as $\mathrm{N}$ addition might do (see "Introduction"), this change may help explain the fact that the two ectomycorrhizal communities in the control and treated plots tend to become more similar again over the years.

\section{Human-induced changes of the soil properties} due to atmospheric $N$ deposition

A second factor to consider may be the continuous longterm atmospheric deposition of $\mathrm{N}$ over the whole study site. We expect an atmospheric input of roughly 
$20 \mathrm{~kg} \mathrm{~N} \mathrm{ha}^{-1}$ year $^{-1}$, according to EKL (2005). The critical loads for $\mathrm{N}$ in Swiss forests are within the range of 8$20 \mathrm{~kg} \mathrm{~N} \mathrm{ha}^{-1}$ year $^{-1}$ (Waldner et al. 2007). Bobbink et al. (1992) cited in Wallenda and Kottke (1998) suggested critical loads of $15-20 \mathrm{~kg} \mathrm{~N} \mathrm{ha}^{-1}$ year $^{-1}$ for changes in sporocarp production of ectomycorrhizal fungi. This means that the atmospheric $\mathrm{N}$ input in our site at least reaches or probably exceeds critical loads affecting forest ecosystems in general and ectomycorrhizal sporocarps in particular. As a consequence we may expect a possible effect of longterm atmospheric $\mathrm{N}$ deposition on fungal communities, affecting also the control plot of the present experiment, i.e. without active $\mathrm{N}$ fertilization. This hypothesis is supported by the temporal pattern of Russula fuscorubroides and Russula laricina, which were shown to be among the four "best differentiating" species between fertilized and control plots at the beginning of the experiment (Peter et al. 2001a). In the last several years of the present experiment, however, these species clearly exhibited a tendency to decrease in the control plot (Online Resource 1). It might also be a reason why the two ectomycorrhizal communities in the control and treated plots tend to become more similar again over the years.

\section{Effects of stand age on fungal communities}

Several studies have demonstrated that the composition of ectomycorrhizal communities changes during forest succession (Last et al. 1987; Kranabetter et al. 2005), and older conifer forests often contain a greater number of fungal species than younger stands (Visser 1995; Rao et al. 1997). Recently, Twieg et al. (2007) demonstrated that simple categories such as 'early stage', 'multi stage', and 'late stage' were insufficient to describe fungal species' successional patterns in Douglas-fir (Pseudotsuga menziesii) stands. They suggest that ectomycorrhizal fungal succession may be better described in the context of stand development. Agreeing with Visser (1995) and Kranabetter et al. (2005), they observed the greatest increase in average site-level diversity in the 5- to 26-year-old age class, a period corresponding to the tree canopy closure, and which increased only slightly thereafter. The spruce trees planted in the 1960s on our site were approximately 40 years old at the beginning and 54 years old at the end of the observation period. The forest stand had been thinned and thereafter reached canopy closure some years before the present experiment started. Therefore, the temporal change in fungal communities that we observed cannot be explained by changes in forest structure, but could be connected to host age.

Acknowledgments We would like to thank the Forest Service of the Canton of Fribourg for its support and for allowing us to use the
Parabock site for this study. The experiment performed at this site complies with the current laws of Switzerland.

\section{References}

Agerer R, Taylor AFS, Treu R (1998) Effects of acid irrigation and liming on the production of sporocarps by ectomycorrhizal fungi. Plant Soil 199:83-89

Alriksson A, Olsson MT (1995) Soil changes in different age classes of Norway spruce (Picea abies (L.) Karst) on afforested farmland. Plant Soil 168:103-110

Anderson MJ (2001) A new method for non-parametric multivariate ANOVA. Austral Ecol 26:32-46

Arnebrant K (1994) Nitrogen amendments reduce growth of extramatrical mycelium. Mycorrhiza 5:7-15

Arnolds E (1991) Decline of ectomycorrhizal fungi in Europe. Agric Ecosyst Environ 35:209-244

BAFU (2007) Stickstoffeinträge im Jahr 2000. Bundesamt für Umwelt BAFU, Bern. http://umweltzustand.admin.ch

Bassin S, Volk M, Suter M, Buchmann N, Fuhrer J (2007) Nitrogen deposition but not ozone affects productivity and community composition of subalpine grassland after three years of treatment. New Phytol 175:523-534

Berg MP, Verhoef HA (1998) Ecological characteristics of a nitrogen-saturated coniferous forest in the Netherlands. Biol Fertil Soils 26:258-267

Borcard D, Legendre P, Drapeau P (1992) Partialling out the spatial component of ecological variation. Ecology 73:1045-1055

BUWAL (1995) Vom Menschen verursachte Luftschadstoff-Emissionen in der Schweiz von 1900 bis 2010. Schriftenreihe Umwelt-Luft, vol 256. Bundesamt für Umwelt, Wald und Landschaft, Bern

Crawley MJ (2002) Statistical computing: an introduction to data analysis using S-PLUS. Wiley, Chichester

Demoling F, Nilsson LO, Baath E (2008) Bacterial and fungal response to nitrogen fertilization in three coniferous forest soils. Soil Biol Biochem 40:370-379

Dix NJ, Webster J (1995) Fungal ecology. Chapman \& Hall, London

Dray S, Chessel D, Thioulouse J (2003) Co-inertia analysis and the linking of ecological data tables. Ecology 84:3078-3089

Egli S, Ayer F (1997) Pilze für den Wald. Schweizer Wald 10:20-23

EKL (2005) Stickstoffhaltige Luftschadstoffe in der Schweiz. In: BUWAL (ed) Status-Bericht der Eidg. Kommission für Lufthygiene (EKL). Bundesamt für Umwelt, Wald und Landschaft, Schriftenreihe Umwelt no. 384, Bern

Erland S, Taylor AFS (2002) Diversity of ecto-mycorrhizal fungal communities in relation to the abiotic environment. In: van der Heiden MGA, Sanders IR (eds) Mycorrhizal ecology. Springer, Berlin, pp 163-200

FAO-UNESCO (1997) Soil map of the world: revised legend. International Soil Reference and Information Centre (ISRIC), Wageningen

Garbaye J, Le Tacon F (1982) Influence of mineral fertilization and thinning intensity on sporocarp production of epigeous fungi in an artificial spruce stand (Picea excelsa L.) in north-eastern France. Acta Oecol 3:153-160

Hassett J, Zak D, Blackwood C, Pregitzer K (2009) Are basidiomycete laccase gene abundance and composition related to reduced lignolytic activity under elevated atmospheric $\mathrm{NO}_{3}{ }^{-}$deposition in a northern hardwood forest? Microb Ecol 57:728-739

Högberg M, Högberg P, Myrold D (2007) Is microbial community composition in boreal forest soils determined by $\mathrm{pH}, \mathrm{C}-$ to-N ratio, the trees, or all three? Oecologia 150:590-601 
Hurlbert SH (1984) Pseudoreplication and the design of ecological field experiments. Ecol Monogr 54:187-211

Jones MD, Durall DM, Cairney JWG (2003) Ectomycorrhizal fungal communities in young forest stands regenerating after clearcut logging. New Phytol 157:399-422

Kernaghan G (2005) Mycorrhizal diversity: cause and effect? Pedobiologia 49:511-520

Knorr M, Frey SD, Curtis PS (2005) Nitrogen additions and litter decomposition: a meta-analysis. Ecology 86:3252-3257

Koide RT, Sharda JN, Herr JR, Malcolm GM (2008) Ectomycorrhizal fungi and the biotrophy-saprotrophy continuum. New Phytol 178:230-233

Kranabetter JM, Friesen J, Gamiet S, Kroeger P (2005) Ectomycorrhizal mushroom distribution by stand age in western hemlocklodgepole pine forests of northwestern British Columbia. Can J For Res 35:1527-1539

Laiho O (1970) Paxillus involutus as a mycorrhizal symbiont of forest trees. Acta For Fenn 106:1-72

Last FT, Dighton J, Mason PA (1987) Successions of sheating mycorrhizal fungi. Trees 2:157-161

Legendre P, Gallagher ED (2001) Ecologically meaningful transformations for ordination of species data. Oecologia 129:271280

Legendre P, Legendre L (1998) Numerical ecology, 2nd edn. Elsevier, Amsterdam

Lilleskov EA, Fahey TJ, Lovett GM (2001) Ectomycorrhizal fungal aboveground community change over an atmospheric nitrogen deposition gradient. Ecol Appl 11:397-410

McArdle BH, Anderson MJ (2001) Fitting multivariate models to community data: a comment on distance-based redundancy analysis. Ecology 82:290-297

Menge JA, Grand LF (1978) Effect of fertilization on production of epigeous basidiocarps by mycorrhizal fungi in loblolly pine plantations. Can J Bot 56:2357-2362

Moser T, Rombke J, Schallnass HJ, Van Gestel CAM (2007) The use of the multivariate principal response curve (PRC) for community level analysis: a case study on the effects of carbendazim on enchytraeids in terrestrial model ecosystems (TME). Ecotoxicology 16:573-583

Nilsson LO, Wallander H (2003) Production and external mycelium by ectomycorrhizal fungi in a Norway spruce forest was reduced in response to nitrogen fertilization. New Phytol 158:409-416

Nohrstedt HO (2001) Response of coniferous forest ecosystems on mineral soils to nutrient additions: a review of Swedish experiences. Scand J For Res 16:555-573

Ohenoja E (1978) Mushrooms and mushroom yields in fertilized forests. Ann Bot Fenn 15:38-46

Oksanen L (2001) Logic of experiments in ecology: is pseudoreplication a pseudoissue? Oikos 94:27-38

Oksanen L (2004) The devil lies in details: reply to Stuart Hurlbert. Oikos 104:598-605

Oksanen J, Kindt R, Legendre P, O’Hara B, Stevens MHM (2008) vegan: Community ecology. $\mathrm{R}$ package version 1.15-0. http:// cran.r-project.org/, http://r-forge.r-project.org/projects/vegan/

Peres-Neto P, Legendre P, Dray S, Borcard D (2006) Variation partitioning of species data matrices: estimation and comparison of fractions. Ecology 87:2614-2625

Peter M, Ayer F, Egli S (2001a) Nitrogen addition in a Norway spruce stand altered macromycete sporocarp production and belowground ectomycorrhizal species composition. New Phytol 149:311-325
Peter M, Ayer F, Egli S, Honegger R (2001b) Above- and belowground community structure of ectomycorrhizal fungi in three Norway spruce (Picea abies) stands in Switzerland. Can J Bot 79:1134-1151

Pregitzer KS, Burton AJ, Zak DR, Talhelm AF (2008) Simulated chronic nitrogen deposition increases carbon storage in northern temperate forests. Glob Change Biol 14:142-153

Rao CS, Sharma GD, Shukla AK (1997) Distribution of ectomycorrhizal fungi in pure stands of different age groups of Pinus kesiya. Can J Microbiol 43:85-91

Rineau F, Garbaye J (2009) Effects of liming on ectomycorrhizal community structure in relation to soil horizons and tree hosts. Fungal Ecol 2:103-109

Ritter G, Tölle H (1978) Stickstoffdüngung in Kiefernbeständen und ihre Wirkung auf Mykorrhizabildung und Fruktifikation der Symbiosepilze. Beitr Forstwirtsch 4:162-166

Rühling Å, Tyler G (1991) Effects of simulated nitrogen deposition to the forest floor on the macrofungal flora of a beech forest. Ambio 20:261-263

Smith SE, Read DJ (2008) Mycorrhizal symbiosis, 3rd edn. Academic Press, London

R Development Core Team (2008) R: a language and environment for statistical computing. R Foundation for Statistical Computing, Vienna. http://www.R-project.org

Termorshuizen AJ, Schaffers AP, Ket PC, Stege EA (1988) The significance of nitrogen pollution on the mycorrhizas of Pinus sylvestris. Air Pollut Res Rep 12:133-139

Toljander JF, Eberhardt U, Toljander YK, Paul LR, Taylor AFS (2006) Species composition of an ectomycorrhizal fungal community along a local nutrient gradient in a boreal forest. New Phytol 170:873-883

Trudell SA, Edmonds RL (2004) Macrofungus communities correlate with moisture and nitrogen abundance in two old-growth conifer forests, Olympic National Park, Washington, USA. Can J Bot 82:781-800

Twieg BD, Durall DM, Simard SW (2007) Ectomycorrhizal fungal succession in mixed temperate forests. New Phytol 176:437-447

van den Brink PJ, ter Braak CJF (1998) Multivariate analysis of stress in experimental ecosystems by principal response curves and similarity analysis. Aquat Ecol 32:163-178

van den Brink PJ, ter Braak CJF (1999) Principal response curves: analysis of time-dependent multivariate responses of biological community to stress. Environ Toxicol Chem 18:138-148

Visser S (1995) Ectomycorrhizal fungal succession in jack pine stands following wildfire. New Phytol 129:389-401

Waldner P, Schaub M, Graf Pannatier E, Schmitt M, Thimonier A, Walthert L (2007) Atmospheric deposition and ozone levels in Swiss forests: are critical values exceeded? Environ Monit Assess 128:5-17

Wallenda T, Kottke I (1998) Nitrogen deposition and ectomycorrhizas. New Phytol 139:169-187

Walthert L, Zimmermann S, Blaser P, Luster J, Lüscher P (2006) Waldböden der Schweiz. Band 1-3. Hep, Bern

Wästerlund I (1982) Försvinner tallens mykorrhizasvampar vid gödsling? Svensk Bot Tidskr 76:411-417

Wiklund K, Nilsson LO, Jacobsson S (1995) Effect of irrigation, fertilization, and artificial drought on basidioma production in a Norway spruce stand. Can J Bot 73:200-208

Zak DR, Holmes WE, Burton AJ, Pregitzer KS, Talhelm AF (2008) Simulated atmospheric $\mathrm{NO}_{3}{ }^{-}$deposition increases soil organic matter by slowing decomposition. Ecol Appl 18:2016-2027 